\title{
Institutional Review Board Independent Ethics Committee Good Clinical Practices Compliance Statement
}

National Cancer Institute

\section{Source}

National Cancer Institute. Institutional Review Board Independent Ethics Committee

Good Clinical Practices Compliance Statement. NCI Thesaurus. Code C115594.

A declaration by the Institutional Review Board (IRB)/Independent Ethics Committee (IEC)

that it is performing its function according to written operating procedures, and is in compliance with Good Clinical Practices (GCP), or applicable regulatory requirements. 